\title{
The $G_{0} / G_{1}$ switch gene 2 is a novel PPAR target gene
}

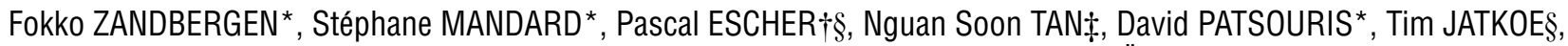 \\ Sandra ROJAS-CARO§, Steve MADORE§, Walter WAHLI†, Sherrie TAFURI§, Michael MÜLLER* and Sander KERSTEN ${ }^{\star 1}$ \\ *Nutrition, Metabolism and Genomics Group, Wageningen University, 6700 EV, Wageningen, The Netherlands, †Institute of Physiology, Pharmazentrum, University of Basel, \\ Basel, CH-4056, Switzerland, †Center for Integrative Genomics, University of Lausanne, Lausanne, CH-1015, Switzerland, and §Pfizer Global Research \& Development, \\ Ann Arbor Laboratories, Molecular Sciences, 2800 Plymouth Road, Ann Arbor, MI 48105, U.S.A.
}

\begin{abstract}
PPARs (peroxisome-proliferator-activated receptors) $\alpha, \beta / \delta$ and $\gamma$ are a group of transcription factors that are involved in numerous processes, including lipid metabolism and adipogenesis. By comparing liver mRNAs of wild-type and PPAR $\alpha$-null mice using microarrays, a novel putative target gene of PPAR $\alpha, G 0 S 2\left(\mathrm{G}_{0} / \mathrm{G}_{1}\right.$ switch gene 2), was identified. Hepatic expression of G0S2 was up-regulated by fasting and by the PPAR $\alpha$ agonist Wy14643 in a PPAR $\alpha$-dependent manner. Surprisingly, the GOS2 mRNA level was highest in brown and white adipose tissue and was greatly up-regulated during mouse 3T3-L1 and human SGBS (SimpsonGolabi-Behmel syndrome) adipogenesis. Transactivation, gel shift and chromatin immunoprecipitation assays indicated that
\end{abstract}

GOS2 is a direct PPAR $\gamma$ and probable $\operatorname{PPAR} \alpha$ target gene with a functional PPRE (PPAR-responsive element) in its promoter. Upregulation of GOS2 mRNA seemed to be specific for adipogenesis, and was not observed during osteogenesis or myogenesis. In 3T3L1 fibroblasts, expression of GOS2 was associated with growth arrest, which is required for 3T3-L1 adipogenesis. Together, these data indicate that GOS2 is a novel target gene of PPARs that may be involved in adipocyte differentiation.

Key words: adipogenesis, $\mathrm{G}_{0} / \mathrm{G}_{1}$ switch gene 2 (GOS2), growth arrest, peroxisome-proliferator-activated receptor (PPAR).

\section{INTRODUCTION}

PPARs (peroxisome-proliferator-activated receptors) represent a group of nuclear receptors that play pivotal roles in the regulation of energy metabolism [1]. These receptors function as ligand-activated transcription factors by binding to the promoters of target genes and inducing transcription upon activation by small lipophilic compounds. Three different PPARs can be distinguished: PPAR $\alpha, \operatorname{PPAR} \beta / \delta$ and PPAR $\gamma$. All three receptors are activated by (mainly polyunsaturated) fatty acids and various fatty-acid-derived compounds, such as eicosanoids.

$\operatorname{PPAR} \gamma$, which is most highly expressed in adipose tissue, is known as the master regulator of adipogenesis. Numerous studies, both in vivo and in vitro, have pointed to PPAR $\gamma$ as the transcription factor that drives adipocyte differentiation [2-5]. The role of PPAR $\gamma$ in adipogenesis is diverse, and concerns the regulation of cell-cycle withdrawal, as well as induction of fat-specific target genes that are involved in adipocyte metabolism. Indeed, PPAR $\gamma$ stimulates the expression of numerous genes that are involved in lipogenesis, including those for aP2 (adipocyte fattyacid-binding protein), lipoprotein lipase and CD36/fatty acid translocase. Previous microarray studies have yielded a comprehensive picture of the likely target genes of PPAR $\gamma$ in adipose tissue and indicate a general role for PPAR $\gamma$ in the regulation of lipid metabolism [6], which is underlined by the therapeutic utilization of the PPAR $\gamma$ ligands thiazolidinediones in obesity-linked Type II diabetes.

Expression of $\operatorname{PPAR} \beta / \delta$ is ubiquitous, which has been a major impediment in elucidating its assorted functions. The most compelling recent studies indicate that $\operatorname{PPAR} \beta / \delta$ stimulates fatty acid oxidation in both adipose tissue and skeletal muscle $[7,8]$, regulates hepatic VLDL (very-low-density lipoprotein) production and catabolism [9], and is involved in wound healing by governing keratinocyte differentiation [10]. Furthermore, $\operatorname{PPAR} \beta / \delta$ has been connected with colon carcinogenesis, although conflicting results have been reported $[11,12]$.

The last PPAR isotype, PPAR $\alpha$, has mostly been studied in the context of liver metabolism and is known to be a central regulator of hepatic fatty acid catabolism [13]. Evidence is accumulating that PPAR $\alpha$ also governs several aspects of glucose metabolism [14]. Furthermore, it potently represses the hepatic inflammatory response by down-regulating the expression of numerous genes $[15,16]$. Indeed, up-regulation of various acute-phase proteins during hepatic inflammation may be linked directly to downregulation of hepatic $\operatorname{PPAR} \alpha$ mRNA under these conditions [17]. Importantly, PPAR $\alpha$ is the molecular target for the hypolipidaemic fibrates, a group of drugs that are prescribed for their ability to lower plasma triacylglycerols and elevate plasma HDL (highdensity lipoprotein) levels.

Although much is already known about PPARs, significant gaps remain in our knowledge, particularly with respect to the set of genes that are regulated by PPARs in various organs. In the present study, we applied microarray technology to find putative targets of PPAR $\alpha$ by comparing liver mRNA from PPAR $\alpha$-knockout mice and wild-type mice. One of the putative target genes identified, called GOS2 $\left(\mathrm{G}_{0} / \mathrm{G}_{1}\right.$ switch gene 2$)$, was subjected to detailed follow-up investigation. The collective data indicate that GOS2 is a direct PPAR target gene, with a functional PPRE

Abbreviations used: aP2, adipocyte fatty-acid-binding protein; Avg Diff, average difference; BAT, brown adipose tissue; BMP-2, bone morphogenetic protein-2; BODIPY ${ }^{\circledR}$, 4,4-difluoro-4-bora-3a,4a-diaza-s-indacene; ChIP, chromatin immunoprecipitation; CYP4A10, cytochrome P450, family 4, subfamily a, polypeptide 10; DMEM, Dulbecco's modified Eagle's medium; DsRed, Discosoma sp. red fluorescent protein; ER, endoplasmic reticulum; GFP, green fluorescent protein; G0S2, Go/G switch gene 2; GPDH, glycerol 3-phosphate dehydrogenase; h, human; HEK-293 cells, human embryonic kidney293 cells; m, mouse; PPAR, peroxisome-proliferator-activated receptor; PPRE, PPAR-responsive element; Q-PCR, real-time quantitative PCR; RT, reverse transcriptase; RXR, retinoid X receptor; SEAP, secreted alkaline phosphatase; SGBS, Simpson-Golabi-Behmel syndrome; WAT, white adipose tissue.

1 To whom correspondence should be addressed (email sander.kersten@wur.nl). 
(PPAR-responsive element) in its promoter, and may be involved in adipocyte differentiation.

\section{EXPERIMENTAL}

\section{Materials}

Wy14643 was obtained from ChemSyn laboratories. Rosiglitazone was from Alexis. Recombinant human insulin (Actrapid) was from Novo Nordisk. Recombinant human BMP-2 (bone morphogenetic protein-2) was from R\&D systems. BODIPY ${ }^{\circledR}(4,4-$ difluoro-4-bora-3a,4a-diaza- $s$-indacene) 493/503 was from Molecular Probes. SYBR Green was from Eurogentec. DMEM (Dulbecco's modified Eagle's medium), foetal calf serum, calf serum and penicillin/streptomycin/fungizone were from Cambrex Bioscience. The 3T3-L1 cell line was purchased from ECACC (European Collection of Cell Culture). HEK-293 (human embryonic kidney-293) cells were from BD Biosciences. All other chemicals were from Sigma.

\section{Animals}

Male pure-bred Sv129 and PPAR $\alpha$-null mice (2-3-month-old) on a Sv129 background were used. Fed mice were killed at the end of the dark cycle. Fasting was started at the onset of the light cycle for 6,12 or $24 \mathrm{~h}$ ( $n=5$ per group). For the feeding experiment with Wy14643, 3-5-month-old male wild-type and PPAR $\alpha$ null mice were fed with $0.1 \%$ Wy 14643 for 5 days by mixing it in their food. Alternatively, they received a single dose of Wy14643 (400 $\mu \mathrm{l}$ of $10 \mathrm{mg} / \mathrm{ml}$ Wy14643 dissolved in $0.5 \%$ carboxymethylcellulose) and were killed $6 \mathrm{~h}$ later $(n=5$ per group). Blood was collected via orbital puncture. Livers were dissected and directly frozen in liquid nitrogen.

The animal experiments were approved by the animal experimentation committee of the Etat de Vaud (Switzerland) or Wageningen University.

\section{Affymetrix microarray}

Total RNA was prepared from mouse livers using TRIzol ${ }^{\circledR}$ reagent (Invitrogen). For each microarray experiment, $10 \mu \mathrm{g}$ of total liver RNA pooled from four mice was used for $c$ RNA synthesis. RNA was pooled because pilot experiments with Affymetrix chips at Pfizer had indicated that the inter-animal variability in gene expression (determined by performing eight separate hybridizations of eight different mice of the same strain), as well as variability between repeated hybridizations of the same pooled RNA sample, were statistically insignificant. Hybridization, washing and scanning of Affymetrix Genechip Mu6500 probe arrays was according to standard Affymetrix protocols. Fluorimetric data were processed by Affymetrix GeneChip3.1 software, and the gene chips were globally scaled to all the probe sets with an identical target intensity value. Affymetrix software measures the expression level of a gene as an average difference value (Avg Diff) by comparing the intensity of hybridization of 20 sets of perfect match oligonucleotide probes to 20 sets of mismatch probes. Only genes with an Avg Diff above the threshold of 100 and with a difference in Avg Diff values between wild-type and $\operatorname{PPAR} \alpha$-null mutant mice at least 2 -fold were considered.

\section{RT (reverse transcriptase)-PCR}

Total RNA was extracted from cells or tissue with TRIzol ${ }^{\circledR}$ reagent following the supplier's protocol. Total RNA $(3-5 \mu \mathrm{g})$ was treated with amplification grade DNAse I (Invitrogen), then reversetranscribed with oligo(dT) using Superscript II RT RNase H(Invitrogen) following the supplier's recommendation. cDNA was
Table 1 Primer pairs used in Q-PCR

\begin{tabular}{|c|c|}
\hline Primer name & Sequence \\
\hline hG0S2 (forward) & 5'-CGCCGTGCCACTAAGGTC-3' \\
\hline hG0S2 (reverse) & 5'-GCACACAGTCTCCATCAGGC-3' \\
\hline m/rGOS2 (forward) & 5'-AGTGCTGCCTCTCTTCCCAC-3' \\
\hline m/rGOS2 (reverse) & 5'-TTTCCATCTGAGCTCTGGGC-3' \\
\hline mPPAR $\gamma$ (forward) & 5'-CACAATGCCATCAGGTTTGG-3' \\
\hline mPPAR $\gamma$ (reverse) & 5'-GCTGGTCGATATCACTGGAGATC-3' \\
\hline mA-FABP (aP2) (forward) & 5'-AAGAAGTGGGAGTGGGCTTT-3' \\
\hline mA-FABP (aP2) (reverse) & 5'-AATCCCCATTTACGCTGATG-3' \\
\hline m0steocalcin (forward) & 5'-GCAGCTTGGTGCACACCTAG-3' \\
\hline m0steocalcin (reverse) & 5'-GGAGCTGCTGTGACATCCAT-3' \\
\hline mGPDH (forward) & 5'-GCCTTCGCCAAGCTCTTCTG-3' \\
\hline mGPDH (reverse) & 5'-TAGCAGGTCGTGATGAGGTCTG-3' \\
\hline $\mathrm{m} \beta$-Actin (forward) & 5'-GATCTGGCACCACACCTTCT-3' \\
\hline $\mathrm{m} \beta$-Actin (reverse) & 5'-GGGGTGTTGAAGGTCTCAAA-3' \\
\hline m36B4 (forward) & 5'-AGCGCGTCCTGGCATTGTGTGG-3' \\
\hline m36B4 (reverse) & 5'-GGGCAGCAGTGGTGGCAGCAGC-3' \\
\hline r36B4 (forward) & 5'-CGGGAAGGCTGTGGTGCTGATG-3' \\
\hline r36B4 (reverse) & 5'-TCGGTGAGGTCCTCCTTGGTGAAC-3' \\
\hline
\end{tabular}

PCR-amplified with Platinum Taq DNA polymerase (Invitrogen). Primer sequences used in the PCRs were chosen based on the sequences available in GenBank ${ }^{\circledR}$. Primer sequences to amplify mG0S2 cDNA were 5'-TGCTGCCTCTCTTCCCACTGC-3' (forward) and 5'-GTAGGGTCAGTTCTGGATTCGGTG-3' (reverse). Other sequences are available from $\mathrm{S}$. K. on request.

\section{Q-PCR (real-time quantitative PCR)}

Primers were designed to generate a PCR-amplification product of 100-200 bp. Only primer pairs yielding unique amplification products without primer dimer formation were subsequently used for Q-PCR assays. The primer pairs listed in Table 1 were used.

PCR was carried out using Platinum Taq polymerase and SYBR green on an iCycler PCR machine (Bio-Rad) according to the instructions from the manufacturer.

\section{Primary hepatocytes}

Rat and mouse hepatocytes were isolated by two-step collagenase perfusion as described previously [18]. Viability was determined by Trypan Blue exclusion, and was at least $75 \%$. Hepatocytes were suspended in William's E medium (Cambrex) supplemented with $10 \%(\mathrm{v} / \mathrm{v})$ foetal calf serum, $20 \mathrm{~m}$-units $/ \mathrm{ml}$ insulin, $50 \mathrm{nM}$ dexamethasone, 100 units of penicillin, $100 \mu \mathrm{g}$ of streptomycin, $0.25 \mu \mathrm{g} / \mathrm{ml}$ fungizone and $50 \mu \mathrm{g} / \mathrm{ml}$ gentamycin. The next day, cells were incubated in fresh medium in the presence or absence of Wy14643 $(25 \mu \mathrm{M})$ for $24 \mathrm{~h}$.

\section{T3-L1 and SGBS (Simpson-Golabi-Behmel syndrome) adipogenesis assay}

3T3-L1 fibroblasts were amplified in DMEM plus $10 \%$ (v/v) calf serum. At 2 days after reaching confluence (=day 0$)$, the medium was changed to DMEM plus $10 \%(\mathrm{v} / \mathrm{v})$ foetal calf serum and the following compounds were added: isobutyl-methylxanthine $(0.5 \mathrm{mM})$, dexamethasone $(1 \mu \mathrm{M})$ and insulin $(5 \mu \mathrm{g} / \mathrm{ml})$. On day 3 , the medium was changed to DMEM plus $10 \%(\mathrm{v} / \mathrm{v})$ foetal calf serum and insulin $(5 \mu \mathrm{g} / \mathrm{ml})$. The medium was subsequently changed every 3 days, and, from day 9 onwards, no further insulin was added.

The culture of the SGBS cells as well as their induction into mature human adipocytes were performed exactly as described previously [19]. 


\section{Western blot}

The combined human/mouse polyclonal antibody used was directed against epitopes TVLGGRALSNRQHAS and EATLCSRALSLRQHAS of the human and mouse G0S2 proteins respectively. The peptide affinity-purified antibodies were generated in rabbit and ordered via Eurogentec's customized antibody production service. Western blot was carried out as described previously [20].

\section{Transactivation assay}

HepG2 cells were co-transfected by calcium phosphate precipitation with an $\operatorname{mPPAR} \alpha$ ( $\mathrm{m}$ is mouse), $\operatorname{mPPAR} \beta / \delta$ or $\operatorname{mPPAR} \gamma 1$ expression vector and pGL3 reporter vector containing different size fragments of the $h G 0 S 2$ (h is human) promoter. A $\beta$-galactosidase reporter vector was co-transfected to normalize for differences in transfection efficiency. After transfection, cells were incubated in the presence or absence of Wy14643 $(50 \mu \mathrm{M})$, L165041 $(5 \mu \mathrm{M})$ or rosiglitazone $(5 \mu \mathrm{M})$ respectively for $24 \mathrm{~h}$ before lysis. A Promega luciferase assay and a standard $\beta$-galactosidase assay using 2 -nitrophenyl- $\beta$-D-galactopyranoside as a substrate were used to measure the relative promoter activities.

To disable the GOS2 PPRE within the hGOS2 promoter, two separate partially overlapping PCR fragments were generated using the wild-type $h G O S 2$ promoter as a template. The mutant sequence was verified by automated sequencing.

A $200 \mathrm{nt}$ fragment surrounding the putative PPRE within the $m G 0 S 2$ promoter was PCR-amplified from mouse genomic DNA (strain C57/B6) and subcloned into the KpnI and BglII sites of pTAL-SEAP (BD Biosciences). This reporter vector was transfected into HepG2 cells by calcium phosphate precipitation together with an expression vector for $\operatorname{mPPAR} \alpha, \operatorname{mPPAR} \beta / \delta$ or $\operatorname{mPPAR} \gamma 1$ in the presence or absence of their respective ligands. A $\beta$-galactosidase reporter was co-transfected to normalize for differences in transfection efficiency. SEAP (secreted alkaline phosphatase) activity was measured in the medium $24 \mathrm{~h}$ posttransfection via the chemiluminescent SEAP reporter assay (Roche).

\section{Gel shift assay}

$\mathrm{hRXR} \alpha$ (retinoid $\mathrm{X}$ receptor), $\mathrm{hPPAR} \alpha$ and $\mathrm{hPPAR} \gamma$ proteins were generated from pSG5 expression vectors using the TNT (transcription and translation)-coupled in vitro system (Promega). The following oligonucleotides were annealed: G0S2-PPRE, 5'CTGGCCAGAAAATTGCAAAGGTCACTGA-3' and 5'-CTGGTCAGTGACCTTTGCAATTTTCTGG-3'; G0S2-PPREmut, 5'-CTGGCCAGAAAATTGCTAAGGACACTGA-3' and 5'-CTGGTCAGTGTCCTTAGCAATTTTCTGG-3'; for specific competition malic enzyme PPRE, 5'-TCGCTTTCTGGGTCAAAGTTGATCCA-3' and 5'-CTGGTGGATCAACTTTGACCCAGAAAG-3'; and for non-specific competition Ets, 5' -TGGAATGTACCGGAAATAACACCA-3' and 5'-TGGTGTTATTTCCGGTACATTCCA-3'. Oligonucleotides were annealed and labelled by Klenow filling (Roche) using Redivue $\left[\alpha-{ }^{32} \mathrm{P}\right] \mathrm{dCTP}(3000 \mathrm{Ci} /$ $\mathrm{mmol}$ ) (Amersham Biosciences). In vitro translated proteins (0.5$0.8 \mu \mathrm{l}$ per reaction) were pre-incubated for $15 \mathrm{~min}$ on ice in $1 \times$ binding buffer [ $80 \mathrm{mM} \mathrm{KCl}, 1 \mathrm{mM}$ dithiothreitol, $10 \mathrm{mM}$ Tris/ $\mathrm{HCl}(\mathrm{pH} 7.4), 10 \%(\mathrm{v} / \mathrm{v})$ glycerol plus protease inhibitors] in the presence of $2 \mu \mathrm{g}$ of poly $(\mathrm{dI}-\mathrm{dC}) \cdot(\mathrm{dI}-\mathrm{dC}), 5 \mu \mathrm{g}$ of sonicated salmon sperm DNA and competitor oligonucleotides in a final volume of $20 \mu \mathrm{l}$. Then $1 \mathrm{ng}(1 \mathrm{ng} / \mu \mathrm{l})$ of radiolabelled oligonucleotide was added, and incubation proceeded for another $10 \mathrm{~min}$ at room temperature $\left(25^{\circ} \mathrm{C}\right)$. Complexes were separated on a $4 \%$ polyacrylamide gel (acrylamide/bisacrylamide, $37.5: 1$ ) equilibrated in $0.5 \times \mathrm{TBE}$ (Tris/borate/EDTA) at $25 \mathrm{~mA}$.

\section{In vivo ChIP (chromatin immunoprecipitation)}

Pure-bred wild-type or PPAR $\alpha$-null mice on a Sv129 background were used. Mice were fed by gavage with either Wy14643 ( $50 \mathrm{mg} / \mathrm{kg}$ per day) or vehicle $(0.5 \%$ carboxymethylcellulose) for 5 days. Alternatively, mice were fasted or not for $24 \mathrm{~h}$. After the indicated treatment, mice were killed by cervical dislocation. The liver was rapidly perfused with pre-warmed $\left(37^{\circ} \mathrm{C}\right)$ PBS for $5 \mathrm{~min}$ followed by $0.2 \%$ collagenase for $10 \mathrm{~min}$. The liver was diced and forced through a stainless steel sieve, and the hepatocytes were collected directly into DMEM containing $1 \%(\mathrm{w} / \mathrm{v})$ formaldehyde. After incubation at $37^{\circ} \mathrm{C}$ for $15 \mathrm{~min}$, the hepatocytes were pelleted, and ChIP was carried out using $\operatorname{PPAR} \alpha$-specific antibodies as described previously [10].

3T3-L1 cells were differentiated as described above. After cell lysis and sonication, the supernatant was diluted 20 -fold in reChIP dilution buffer (1 mM EDTA, $20 \mathrm{mM}$ Tris/HCl, pH 8.1, $50 \mathrm{mM} \mathrm{NaCl}$ and $1 \%$ Triton X-100) before incubation with antibodies against mouse $\operatorname{PPAR} \gamma$ or $\operatorname{PPAR} \beta / \delta$. The remainder of the assay was carried out as described previously [10]. PCR was performed using primers flanking the putative PPRE in the $m G 0 S 2$ promoter (amplified product -1937 to -1357 ) and a control sequence (amplified product -3555 to -3107 ).

\section{C2C12 osteo- and myo-genesis}

C2C12 mesenchymal progenitor cells were differentiated into myoblasts by letting the cells grow to confluence. $\mathrm{C} 2 \mathrm{C} 12$ cells were differentiated into osteoblasts by the addition of BMP-2 $(500 \mathrm{ng} / \mathrm{ml})$.

\section{Cell-cycle synchronization}

3T3-L1 cells were seeded at low confluence in DMEM plus $10 \%$ $(\mathrm{v} / \mathrm{v})$ foetal calf serum. After $9 \mathrm{~h}$, the medium was replaced by DMEM plus $0.2 \%(\mathrm{v} / \mathrm{v})$ foetal calf serum for $33 \mathrm{~h}$. After that, foetal calf serum was re-added to the cells at $10 \%$, and cells were taken at regular intervals for RNA preparation.

\section{Cellular localization studies}

The $m G 0 S 2$ open reading frame was cloned into the EcoRI and BamHI sites of pEGFP-N2 and pDsRed1-N1 (BD Biosciences). The ER (endoplasmic reticulum) localization vector $\mathrm{pDsRed2-ER}$ (BD Biosciences) was used as a control vector for the ER. The $m G 0 S 2$-containing pEGFP-N2 vector was co-transfected with pDsRed2-ER into HEK-293 cells. The mG0S2-containing pDsRed1-N1 vector was transfected into 3T3-L1 cells. Transfections were performed by calcium phosphate precipitation on $60 \%$ confluent cell cultures. For 3T3-L1 cells, after 8 h, medium was replaced with medium containing $0.1 \%$ (v/v) Tween 80 . After $48 \mathrm{~h}$, cells were washed with PBS and fixed in $3.5 \%(\mathrm{w} / \mathrm{v})$ formaldehyde in PBS. BODIPY ${ }^{\circledR} 493 / 503$ (saturated solution in $100 \%$ ethanol) was added to the fixing solution at 1:100, after which the cells were examined by fluorescence spectroscopy. Fluorescence microscopy was carried out $48 \mathrm{~h}$ post-transfection using a LSM510 confocal laser-scanning microscope (Zeiss).

\section{RESULTS}

\section{Microarray studies identify the GOS2 gene as a potential PPAR target gene}

Microarray studies permit the expression monitoring of thousands of genes. To identify new putative PPAR target genes, mRNA from livers of wild-type and PPAR $\alpha$-null mice at different stages of fasting was compared using Affymetrix murine 6500 oligonucleotide microarrays. 
Table 2 Genes differentially expressed between wild-type and PPAR $\alpha$-null mice in fasted (top list) and fed (bottom list) state according to microarray analysis

Fold D., fold difference; FXR, farnesoid X receptor; RIP14, receptor-interacting protein 14; ss, single-stranded.

\begin{tabular}{|c|c|c|c|c|}
\hline Accession no. & Gene & Fold D. & Avg Dif & Function \\
\hline X69296 & Fatty acid $\omega$ hydroxylase (CYP4A10) & 56.5 & 120.4 & Fatty acid oxidation/ketogenesis \\
\hline X95280 & GOS2 & 9.2 & 152.6 & Unknown \\
\hline M13366 & NAD-linked GPDH & 7.5 & 167.2 & Glycerol metabolism \\
\hline U14390 & Aldehyde dehydrogenase 3 & 7.4 & 371.9 & Biotransformation \\
\hline U12791 & HMG-CoA synthase (hydroxymethylglutaryl-CoA synthase) & 7.3 & 1490.1 & Fatty acid oxidation/ketogenesis \\
\hline Z14050 & Dodecenoyl-CoA $\delta$ isomerase & 5.5 & 423.5 & Fatty acid oxidation/ketogenesis \\
\hline X89998 & $17 \beta$-Hydroxysteroid dehydrogenase type IV & 5.2 & 494.7 & Steroid metabolism \\
\hline L11163 & Short-chain-acyl-CoA dehydrogenase & 5 & 208.9 & Fatty acid oxidation/ketogenesis \\
\hline U01163 & Carnitine palmitoyltransferase II & 4.1 & 505.3 & Fatty acid oxidation/ketogenesis \\
\hline U60987 & FAD-linked GPDH & 4.1 & 172.8 & Glycerol metabolism \\
\hline L40406 & Heat-shock protein $105 \mathrm{kDa} \beta$ & 4 & 150.8 & Heat-shock protein \\
\hline X74938 & HNF3 $\gamma$ (hepatic nuclear factor $3 \gamma$ ) & 3.5 & 103.2 & Transcription factor \\
\hline J03398 & ABC-B4 (ATP-binding cassette B4) (mdr2) & 3.4 & 642.2 & Transporter \\
\hline M22432 & Protein synthesis elongation factor Tu & 3.3 & 186.9 & Protein synthesis \\
\hline L05439 & Insulin-like growth factor-binding protein 2 & 3.2 & 2083.7 & Plasma-binding protein \\
\hline X85983 & Carnitine acetyltransferase & 3.2 & 424.5 & Fatty acid oxidation/ketogenesis \\
\hline U41497 & Very-Iong-chain-acyl-CoA dehydrogenase & 3.1 & 659.1 & Fatty acid oxidation/ketogenesis \\
\hline U58883 & CAP (c-Cbl-associated protein) & 3 & 158.8 & Insulin signalling \\
\hline X78709 & NRF1 (nuclear respiratory factor 1) & 2.9 & 144.8 & Transcription factor \\
\hline U09010 & Mannose-binding protein A (Mbl1) & 2.9 & 577.2 & Immune function? \\
\hline X98848 & 6-Phosphofructo-2-kinase/fructose 2,6-bisphosphate & 2.8 & 115.2 & Glucose metabolism \\
\hline U33557 & Folylpolyglutamate synthetase & 2.6 & 275 & Folate metabolism \\
\hline J02652 & Malate NADP-oxidoreductase (malic enzyme) & 2.6 & 158.2 & Fatty acid synthesis \\
\hline U44389 & NAD-dependent 15-hydroxyprostaglandin dehydrogenase & 2.5 & 244.7 & Eicosanoid metabolism \\
\hline AA120387 & Mitochondrial Lon protease holomogue 1 precursor & 2.5 & 535.4 & Unknown \\
\hline AA016431 & E-FABP (epidermal fatty-acid-binding protein) & 2.5 & 157.2 & Fatty acid binding \\
\hline U02098 & Pur $\alpha$ & 2.5 & 122.2 & ssDNA-binding protein \\
\hline U09416 & Bile acid receptor (BAR) (FXR, RIP14) & 2.5 & 505.7 & Transcription factor \\
\hline Y00309 & Lactate dehydrogenase $\mathrm{A}$ & 2.4 & 4506.4 & Glucose metabolism \\
\hline U15977 & Long-chain-acyl-CoA synthetase & 2.4 & 1214.7 & Fatty acid activation \\
\hline U15977 & Long-chain-acyl-CoA dehydrogenase & 2.4 & 301 & Fatty acid oxidation/ketogenesis \\
\hline Z19581 & Siah-2 protein & 2.4 & 107 & Unknown \\
\hline U41751 & El24 (etoposide-induced protein 2.4) & 2.3 & 276.5 & Cell growth/apoptosis \\
\hline J05186 & ERp72 (endoplasmic reticulum protein $72 \mathrm{kDa}$ ) & 2.3 & 286.5 & Heat-shock protein \\
\hline U48420 & Gluthatione transferase type $2 \theta$ class & 2.3 & 809.8 & Biotransformation \\
\hline U57368 & DBI-1 (epidermal growth factor repeat transmembrane protein) & 2.3 & 102.1 & Mitogen signalling? \\
\hline X70887 & p59 immunophilin & 2.3 & 259.9 & Binds heat-shock proteins \\
\hline D49744 & Farnesyltransferase $\alpha$ subunit & 2.2 & 339.9 & Post-translational processing \\
\hline M65255 & Hydrophilic protein KE2 & 2.2 & 130.1 & Unknown \\
\hline X674689 & LRP1 (LDL receptor-related protein 1) & 2.2 & 402.1 & Cholesterol metabolism \\
\hline D29639 & 3-Hydroxyacyl-CoA dehydrogenase & 2.2 & 2020.7 & Fatty acid oxidation/ketogenesis \\
\hline AA028398 & Tubulin $\beta$ & 2.2 & 107.8 & Cytoskeleton \\
\hline X51971 & Carbonic anhydrase $\mathrm{V}$ & 2.1 & 186.7 & Ureagenesis/gluconeogenesis \\
\hline U76832 & Plasma membrane protein syntaxin & 2.1 & 148.3 & Endo-/exo-cytosis \\
\hline U49878 & HMG-CoA lyase (hydroxymethylglutaryl-CoA lyase) & 2.1 & 1933.9 & Fatty acid oxidation/ketogenesis \\
\hline U48403 & Glycerol kinase & 2.1 & 164 & Glycerol metabolism \\
\hline AA068057 & Ras-related protein RAB21 & 2 & 199.8 & Vesicular transport \\
\hline U06837 & $\beta$-Hexosaminidase & 2 & 114.6 & Lysosomal enzyme \\
\hline W30496 & Galactokinase & 2 & 139.7 & Galactose metabolism \\
\hline U07159 & Medium-chain-acyl-CoA dehydrogenase & 2 & 2037.1 & Fatty acid oxidation/ketogenesis \\
\hline M13522 & Serum amyloid $A$ isoform 2 & 15.2 & 829.2 & Acute-phase protein \\
\hline M13521 & Serum amyloid $\mathrm{A}$ isoform 1 & 11.9 & 1194.9 & Acute-phase protein \\
\hline V00835 & Metallothionein-I & 5.9 & 130.8 & Acute-phase protein \\
\hline M21285 & Stearoyl-CoA desaturase 1 & 3.2 & 2099.9 & Fatty acid desaturation \\
\hline U73037 & Interferon regulatory factor 7 & 2.9 & 101.5 & Transcription factor \\
\hline Z14050 & Dodecenoyl-CoA $\delta$-isomerase & 2.8 & 331.7 & Fatty acid oxidation \\
\hline X64070 & Mannose phosphate receptor 46 & 2.3 & 109.3 & Lysosomal transport \\
\hline M96823 & Nucleobindin (Calnuc) & 2.2 & 296.9 & $\mathrm{Ca}^{2+}$ binding protein \\
\hline U01163 & Carnitine palmitoyl-transferase II & 2.1 & 536.7 & Fatty acid oxidation \\
\hline X07295 & Mitochondrial malate dehydrogenase & 2 & 295.5 & TCA cycle \\
\hline M28666 & Porphobilinogen deaminase & 2 & 663.6 & Haem synthesis \\
\hline
\end{tabular}

Out of a total of 6519 genes present on the array, mRNA levels of 50 genes were at least 2-fold lower in the livers of 24-h-fasted $\operatorname{PPAR} \alpha$-null mice compared with 24-h-fasted wild-type mice. In fed mice, the number of genes fulfilling the same criteria was much lower (11 genes) (Table 2), indicating that deletion of the PPAR $\alpha$ gene has much more severe consequences in the fasted state than in the fed state. Interestingly, there was very little overlap between the two sets of genes. 


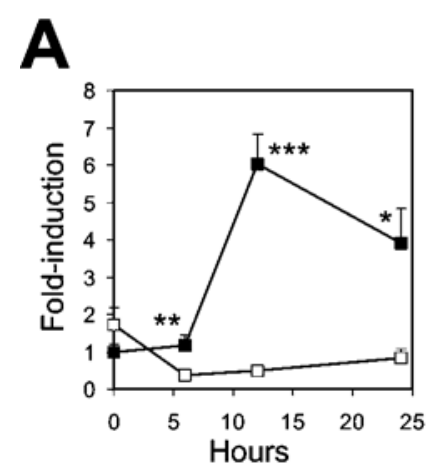

D

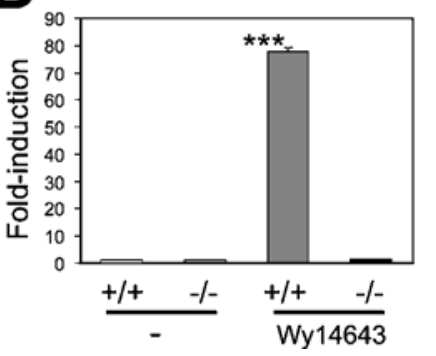

C

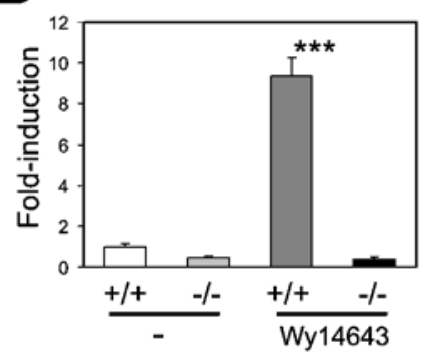

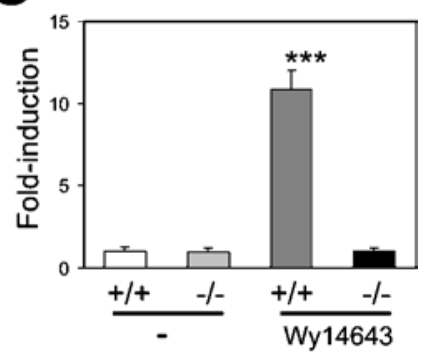

Figure 1 GOS2 is a PPAR $\alpha$-regulated gene in mouse

(A) Hepatic expression of G0S2 after 0, 6, 12 or 24 h of fasting in wild-type ( $\mathbf{\square})$ and PPAR $\alpha$-null mice ( $\square)$. (B) Hepatic G0S2 expression in wild-type (+/+) and PPAR $\alpha$-null (-/-) mice $6 \mathrm{~h}$ after oral gavage of $4 \mathrm{mg}$ of Wy14643. (C) Hepatic G0S2 expression in wild-type (+/+) and PPAR $\alpha$-null (-/-) mice after 5 days of feeding with Wy14643 (0.1\%). (D) G0S2 expression in primary hepatocytes of wild-type (+/+) and PPAR $\alpha$-null (-/-) mice incubated for $24 \mathrm{~h}$ in the presence or absence of Wy14643 (25 $\mu \mathrm{M})$. (E) G0S2 expression in primary rat hepatocytes incubated for $24 \mathrm{~h}$ in the presence or absence of Wy14643 $(25 \mu \mathrm{M})$. G0S2 expression was determined by Q-PCR. Results are means \pm S.E.M. Differences were evaluated by student's $t$ test $\left({ }^{\star} P<0.05\right.$, ${ }^{\star \star} P<0.01$, $\left.{ }^{\star \star \star} P<0.001\right)$.

Many of the genes that were down-regulated in the PPAR $\alpha$-null mice compared with the wild-type mice after $24 \mathrm{~h}$ of fasting are classical PPAR $\alpha$ target genes involved in fatty acid oxidation and ketogenesis, including CYP4A10 (cytochrome P450, family 4, subfamily a, polypeptide 10), HMG-CoA synthase (hydroxymethylglutaryl-CoA synthase), very-long-chain-acyl-CoA dehydrogenase and many others. However, there were also a significant number of differentially expressed genes that thus far have not been associated with PPAR $\alpha$ and may represent novel $\operatorname{PPAR} \alpha$ target genes. Of these genes, G0S2, which encodes a small protein of unknown function, showed the largest decrease in mRNA levels in PPAR $\alpha$-null mice second to CYP4A10.

The GOS2 gene was first identified approx. 10 years ago in a screen to find genes that are differentially expressed during the lectin-induced switch of lymphocytes from $G_{0}$ to the $G_{1}$ phase of the cell cycle. It was found that GOS 2 expression increased transiently within $1-2 \mathrm{~h}$ of addition of lectin or cycloheximide to blood mononuclear cells [21]. Additional information about the potential function of this gene is lacking. The G0S2 gene encodes a protein of 103 amino acids with $78 \%$ identity between mouse and human and contains one predicted transmembrane domain. Remarkably, G0S2 protein seems to be unique: no homologous protein could be found in lower organisms (including Caenorhabditis elegans and Drosophila), and it does not seem to contain any domain shared by other proteins.

Q-PCR analysis showed that hepatic expression of G0S2 was highly increased during fasting, reaching a peak after $12 \mathrm{~h}$ (Figure $1 \mathrm{~A}$ ). This fasting-induced increase in expression was absent in PPAR $\alpha$-null mice. Administration of the synthetic PPAR $\alpha$ agonist Wy14643 increased G0S2 mRNA in mouse liver (Figure 1B and 1C) and primary hepatocytes (Figure 1D) of wild-type, but not PPAR $\alpha$-null, mice. Furthermore, addition of Wy14643 increased

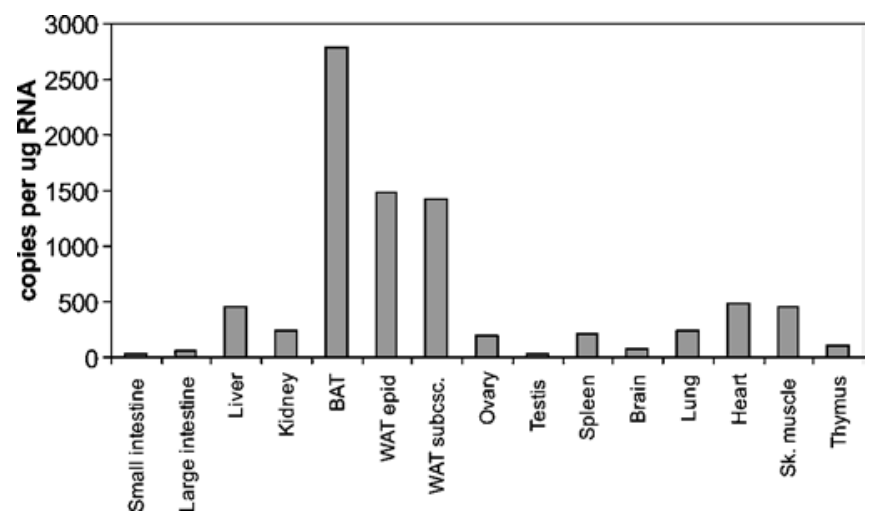

Figure 2 GOS2 is expressed mainly in adipose tissue

Total RNA was prepared from tissues of one adult male mouse (NMRI strain) and GOS2 expression was determined by Q-PCR. Ovary was sampled from a female mouse of the same age and strain. WAT epid, epididymal WAT; WAT subsc., subscapular WAT; Sk. muscle, skeletal muscle.

GOS2 mRNA expression in primary rat hepatocytes (Figure 1E). These results suggest that GOS2 may be a direct target gene of $\operatorname{PPAR} \alpha$.

\section{GOS2 is connected with adipocyte differentiation}

Although G0S2 was identified in liver, it may be expressed elsewhere as well. Indeed, Q-PCR showed that G0S2 mRNA levels were highest in BAT (brown adipose tissue) and WAT (white adipose tissue), followed by muscle, heart and liver (Figure 2). In contrast, expression was very low in testes, small and large intestine, and thymus. While PPAR $\alpha$ is highly expressed in BAT 

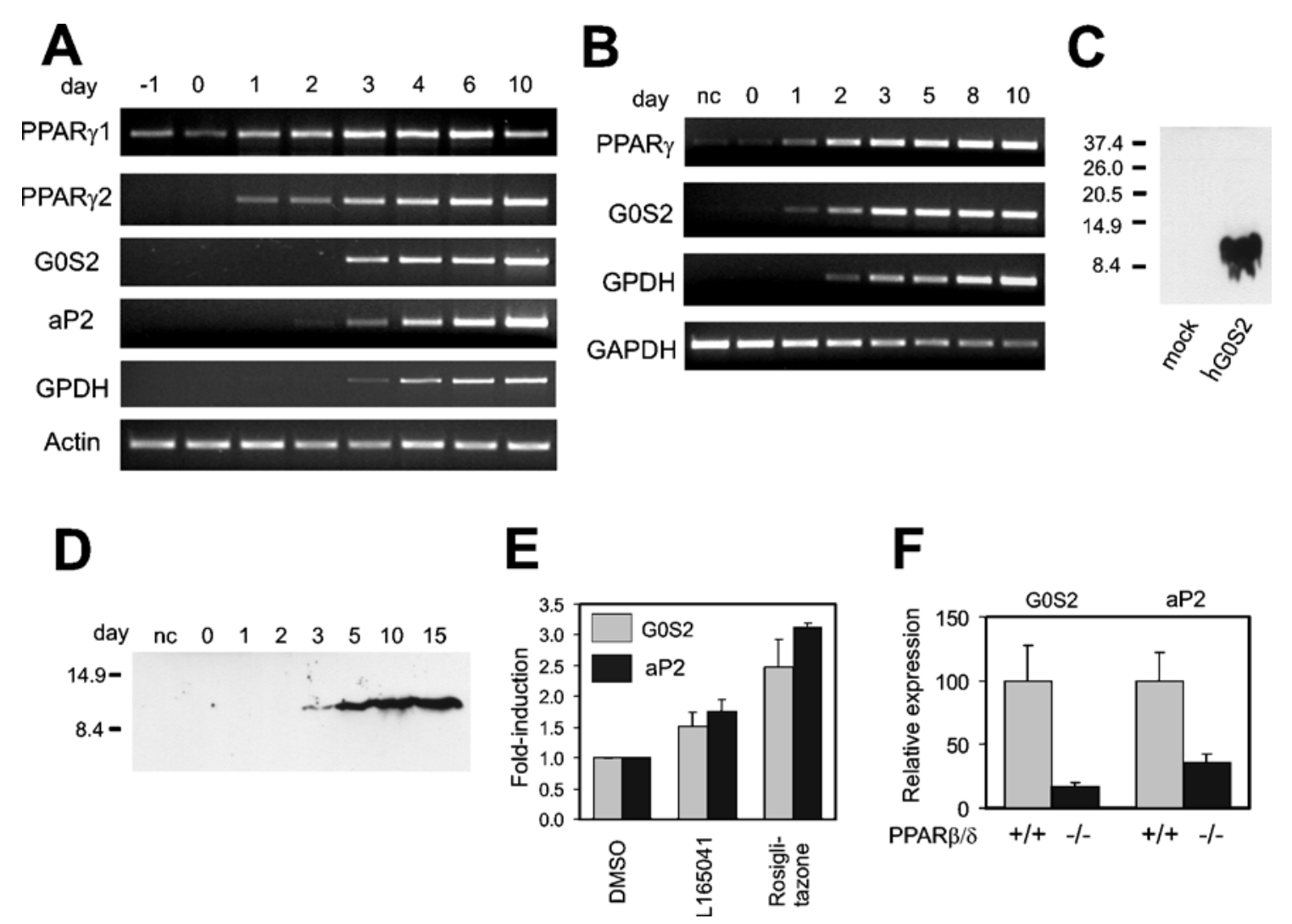

\section{Figure 3 GOS2 mRNA expression is induced during 3T3-L1 and SGBS adipogenesis}

Post-confluent 3T3-L1 (A) or SGBS (B) fibroblasts were induced to differentiate into adipocytes. Expression of GOS2 and several adipogenic genes was determined at regular intervals by RT-PCR. (C) HEK-293 cells were transfected with empty vector (lane 1) or vector expressing hGOS2 (lane 2). Molecular-mass sizes are given in $\mathrm{kDa}$. (D) Lysates from SGBS cells at different stages of differentiation were analysed for hGOS2 protein by Western blotting (15 $\mu \mathrm{g}$ of protein/lane) using a polyclonal anti-GOS2 antibody. Molecular-mass sizes are given in kDa. (E) Differentiated 3T3-L1 cells at day 10 were incubated with L165041 $(2.5 \mu \mathrm{M})$ or rosiglitazone $(1 \mu \mathrm{M})$ for $40 \mathrm{~h}$, and the effect on GOS2 and aP2 expression was determined by Q-PCR. Results are means \pm S.E.M. (F) GOS2 and aP2 mRNA were measured by Q-PCR in WAT of wild-type (+/+) and PPAR $\beta / \delta$-null (-/-) mice. Results are means \pm S.E.M.

and liver, it is virtually absent from WAT. In contrast, PPAR $\gamma$ is highly expressed in WAT, where it plays an important role in adipocyte differentiation. The high expression of GOS2 in WAT suggests that it could be a target of PPAR $\gamma$. To find out whether this is true, the 3T3-L1 adipogenesis system was used. Expression of GOS2 rose dramatically during 3T3-L1 adipocyte differentiation, shortly after PPAR $\gamma 1$ and 2 (Figure 3A). Quantification of the changes in expression by Q-PCR indicated that GOS2 mRNA levels went up approx. 250-fold from day 0 to day 10 (see Figure 7). To find out whether GOS2 is similarly upregulated during human adipogenesis, expression was monitored during human SGBS adipocyte differentiation. Similarly to that in 3T3-L1 cells, GOS2 was dramatically increased during SGBS adipogenesis (over 300-fold according to Q-PCR; see Figure 7), again shortly after PPAR $\gamma$ and jointly with the adipogenic marker GPDH (Figure 3B). According to Western blot using an anti-G0S2 antibody (Figure 3C), in parallel with the mRNA data with a delay of 1-2 days, a clear increase in G0S2 protein was observed, indicating that changes at the mRNA level were translated at the protein level (Figure 3D). Taken together, these data demonstrate that GOS2 expression is highly up-regulated during mouse and human adipocyte differentiation, together with PPAR $\gamma$ targets and late adipogenesis marker genes $a P 2$ and $G P D H$, suggesting that GOS 2 may be regulated directly by $\operatorname{PPAR} \gamma$.

To substantiate further this notion, differentiated 3T3-L1 cells were treated with the synthetic PPAR $\gamma$ agonist rosiglitazone. Rosiglitazone at $1 \mu \mathrm{M}$ caused an increase in G0S2 expression of approx. 2.5-fold, while the $\operatorname{PPAR} \beta / \delta$ agonist L165041, at a concentration at which it specifically activates $\operatorname{PPAR} \beta / \delta$ [22], increased G0S2 mRNA approx. 1.5-fold (Figure 3E). Similar changes in gene expression were observed for $a P 2$, a well known $\operatorname{PPAR} \gamma$ target gene. Regulation by $\operatorname{PPAR} \beta / \delta$ was confirmed by the significantly decreased expression of GOS 2 in WAT of homozygous PPAR $\beta / \delta$-null mice (Figure 3F). Together, these data suggest that GOS2 may be a direct target gene of PPAR $\gamma$ and possibly $\operatorname{PPAR} \beta / \delta$.

\section{A PPRE is present within the GOS2 promoter}

To determine what genomic region is responsible for PPARinduced up-regulation of GOS2 expression, $2.2 \mathrm{~kb}$ of $h G 0 S 2$ promoter sequence immediately upstream of the transcription start site was cloned in front of a luciferase reporter, and transactivation studies were carried out in HepG2 cells. Whereas PPAR $\gamma$ markedly increased reporter activity (Figure 4A), the other receptors showed little to no effect. This response to PPAR $\gamma$ and its ligand was abolished completely upon deletion of the promoter to 1.0, 0.5 or $0.27 \mathrm{~kb}$ (Figure 4B), indicating that the PPRE was located in the region between -2.2 and $-1 \mathrm{~kb}$. Interestingly, after deleting the promoter to $1.0,0.5$ or $0.27 \mathrm{~kb}, \operatorname{PPAR} \alpha$ and $\mathrm{Wy} 14643$ decreased reporter activity (Figure 4B), suggesting that regulation of GOS 2 promoter activity by $\operatorname{PPAR} \alpha$ is more complex.

In the region -2.2 to $-1 \mathrm{~kb}$, a $45 \mathrm{bp}$ sequence was identified that was extremely well conserved between the mouse and human 


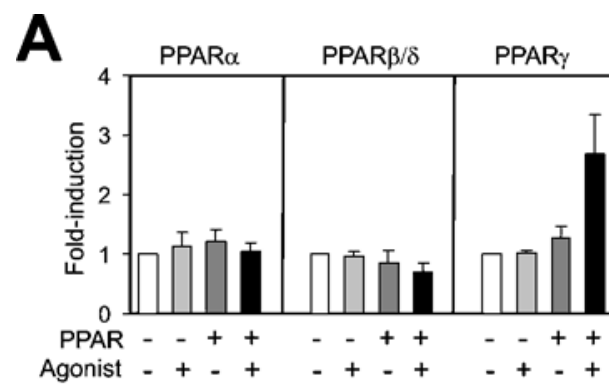

B

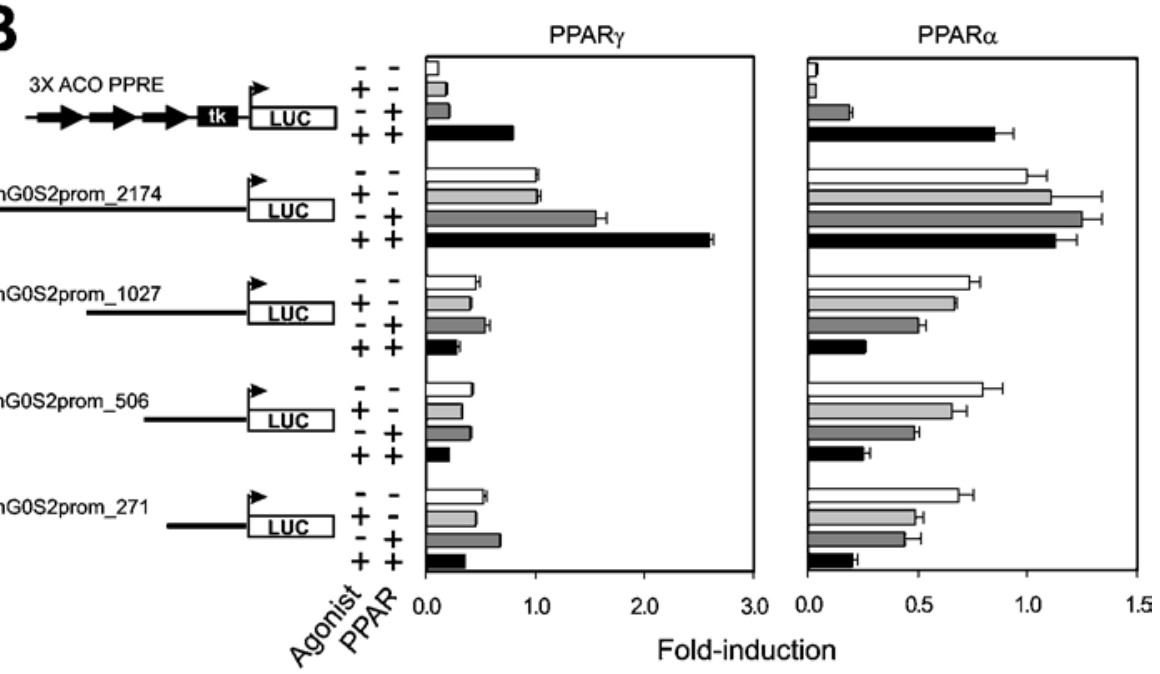

C

mG0S2 1500-AGGCTGTTGCAAGATTGCATCAGTGACCTTTGCAATTTTCTGGCCAGTT-1451

||||||||||||||||||||||||||||||||||||||||||||||||

hG0S2 1362-AGGCTGTTGCAAGATTGCATCACTGACCTTTGCAATTTTCTGGCCAGTT-1313

D

\begin{tabular}{|ll|}
\hline Human G0S2 & agaaaATTGCAAAGGTCA \\
Mouse G0S2 & agaaaATGCAAAGGTCA \\
Rat ACO & ggaccAGGACAAAGGTCA \\
Rabbit Cyp4A6 & gaactAGGGCAAAGTTCA \\
\hline
\end{tabular}

Figure 4 GOS2 promoter is regulated by PPARs

(A) hGOS2 reporter construct containing 2174 bp of immediate upstream promoter region was transfected into HepG2 cells together with a PPAR expression vector. Transfected cells were incubated for $24 \mathrm{~h}$ in the presence or absence of ligand. Normalized luciferase activity in the absence of PPAR and ligand was set at 1. Results are means \pm S.E.M. for at least three independent experiments. (B) hG0S2 reporter constructs containing 2174, 1027, 506 or 271 bp of immediate upstream promoter region were transfected into HepG2 cells together with an mPPAR 1 or mPPAR $\alpha$ expression vector. Transfected cells were incubated for $24 \mathrm{~h}$ in the presence or absence of ligand. A luciferase reporter containing three copies of the acyl-CoA oxidase PPRE was used as a positive control. Normalized luciferase activity of the 2174 bp reporter in the absence of PPAR and ligand was set at 1. Results are means + S.E.M. (C) Alignment of a putative regulatory region within mGOS2 and hGOS2 promoter about $1.5 \mathrm{~kb}$ upstream of transcription start site. The putative PPRE is underlined. (D) Alignment of a putative PPRE present within GOS2 promoter with established PPRES. Lower-case letters indicate the DNA base-pair sequence preceding the PPRE, which is represented by upper-case letters.

GOS2 promoter, suggesting that it is important for regulation (Figure 4C). Close inspection of this sequence revealed the presence of a putative PPRE that is highly homologous with existing PPREs (Figure 4D).

To determine whether this PPRE binds PPAR in vitro, we performed a gel shift assay. In the presence of PPAR $\alpha$ or RXR $\alpha$ only, a single complex was observed, which originated from the reticulocyte lysate (Figure 5A). An additional, more intense, slower moving complex was observed only in the presence of both receptors, indicating that it represents a PPAR-RXR heterodimer. The complex disappeared in the presence of an excess of unlabelled specific oligonucleotide, but not non-specific oligo- nucleotide. The PPAR-RXR heterodimer did not form on an oligonucleotide that contained two substitutions within the GOS2 PPRE. Very similar results were observed for PPAR $\gamma$ (Figure 5A, right-hand panel) and $\mathrm{PPAR} \beta / \delta$ (results not shown). These results indicate that all three PPARs are able to bind to the GOS2 PPRE in vitro.

To assess whether the GOS2 PPRE is able to mediate PPARdependent transactivation, a 200-nucleotide fragment surrounding the human PPRE was cloned in front of the thymidine kinase promoter followed by an SEAP reporter. In a transactivation assay, the reporter responded to $\operatorname{PPAR} \alpha, \operatorname{PPAR} \beta / \delta$ and $\operatorname{PPAR} \gamma$ (Figure 5B), indicating that the PPRE identified is functional. The 

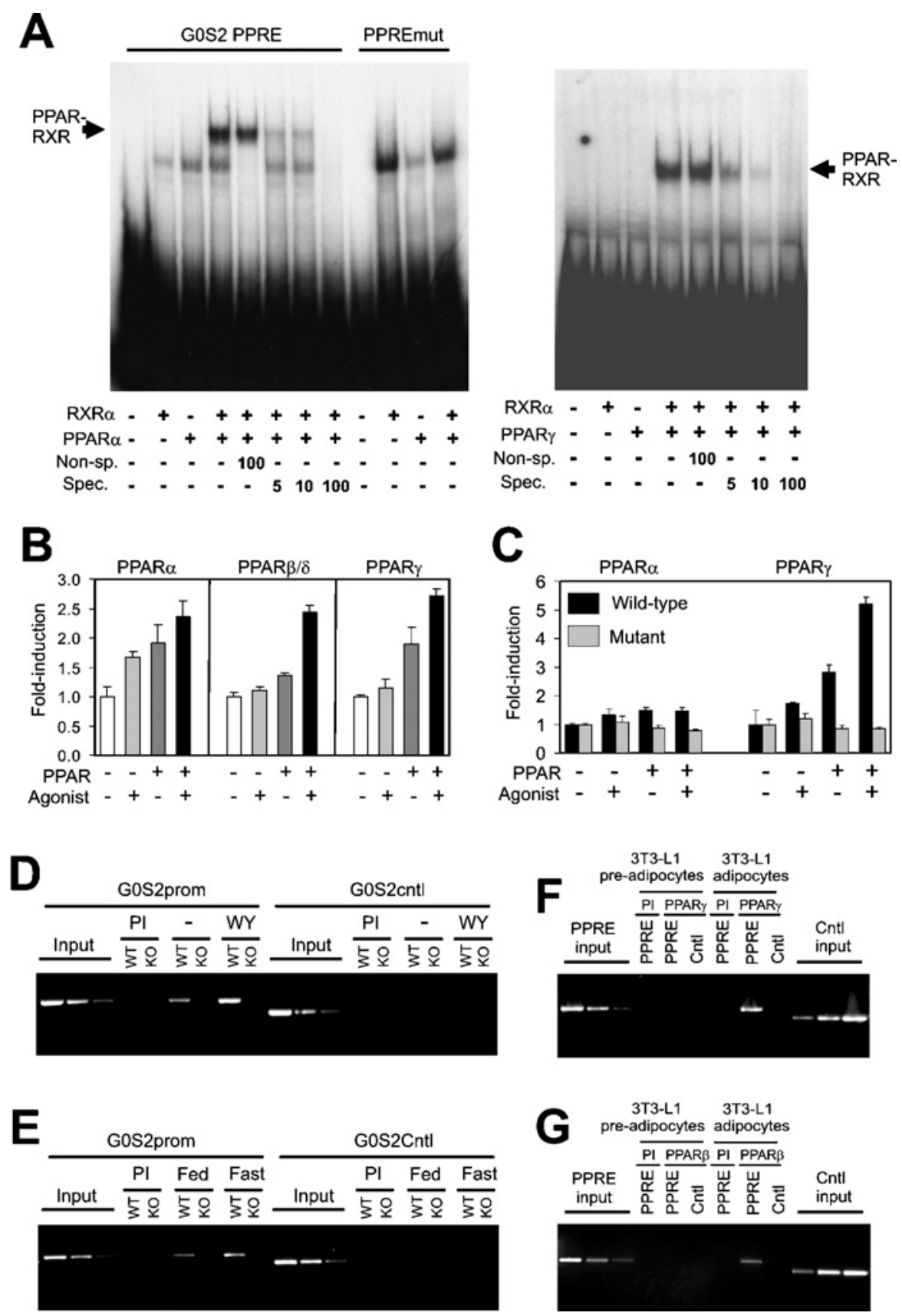

\section{Figure 5 GOS2 is a direct PPAR target gene}

(A) Binding of the PPAR-RXR heterodimer to the putative GOS2 PPRE as determined by gel shift assay. A double-stranded oligonucleotide containing the GOS2 PPRE was incubated with in vitro transcribed/translated hRXR $\alpha$ and hPPAR $\alpha$ (left-hand panel) or hPPAR $\gamma$ (right-hand panel), and binding complexes were separated by electrophoresis. Fold-excess of specific (Spec.: malic enzyme PPRE) or non-specific (Non-sp.: Ets oligonucleotide) unlabelled probe is indicated. (B) HepG2 cells were transfected with a SEAP reporter vector containing a $200 \mathrm{bp}$ fragment of the mGOS2 promoter and a PPAR expression vector. SEAP activity was determined in the medium $24 \mathrm{~h}$ post-transfection and normalized to $\beta$-galactosidase. Normalized SEAP activity in the absence of PPAR and ligand was set at 1. Results are means +S.E.M. (C) Reporter vector containing $2174 \mathrm{bp}$ of $h G 0 S 2$ promoter, with or without the PPRE disabled by site-directed mutagenesis, was transfected into HepG2 cells together with an expression vector for mPPAR $\alpha$ or mPPAR $\gamma$. Normalized luciferase activity in the absence of PPAR and ligand was set at 1. Results are means \pm S.E.M. (D-G) ChIP of GOS2 PPRE using antibodies against mPPAR $\alpha, \mathrm{mPPAR} \gamma$ or mPPAR $\beta / \delta$. The gene sequence spanning the putative PPRE and a random control sequence (Cntl) were analysed by PCR in the immunoprecipitated chromatin of livers of wild-type (WT) and PPAR $\alpha$-null (KO) mice treated or not with Wy14643 (D), livers of fed or fasted wild-type (WT) and PPAR $\alpha$-null (K0) mice (E), and 3T3-L1 pre-adipocytes and adipocytes (F) and (G). Pre-immune serum (PI) was used as a control.

importance of the GOS2 PPRE for PPAR-dependent promoter activation was shown by the failure of PPAR $\gamma$ to stimulate $h G 0 S 2$ promoter activity when, within the complete $2.2 \mathrm{~kb}$ promoter reporter construct, the PPRE was disabled (Figure 5C). Supporting the results in Figure 4(A), PPAR $\alpha$ decreased reporter activity of this mutated promoter construct.
Finally, to investigate whether PPAR $\alpha$ is bound to the GOS2 PPRE in mouse liver, in vivo ChIP was performed using an antiPPAR $\alpha$ antibody. In mice, treatment with Wy14643 enhanced binding of PPAR $\alpha$ to the PPRE sequence in liver, which was not observed in PPAR $\alpha$-null mice (Figure 5D). Similarly, fasting enhanced binding of PPAR $\alpha$ to the PPRE sequence, which 
was not observed in the $\operatorname{PPAR} \alpha$ null mice (Figure 5E). No detectable immunoprecipitation was observed with pre-immune serum and no amplification was observed for a control sequence. Furthermore, using ChIP, we observed binding of PPAR $\gamma$ (Figure $5 \mathrm{~F}$ ) and PPAR $\beta / \delta$ (Figure $5 \mathrm{G}$ ) to the PPRE sequence in differentiated 3T3-L1 adipocytes, but not in pre-adipocytes. These results demonstrate that $\operatorname{PPAR} \alpha, \operatorname{PPAR} \gamma$, and $\operatorname{PPAR} \beta / \delta$ bind to the PPRE identified within the GOS2 promoter in vivo. Thus GOS2 can be formally classified as a direct PPAR target gene in human and mouse.

\section{GOS2 protein can be localized to the ER}

To get a better understanding of the function of G0S2, it is important to determine its intracellular localization. The presence of a single transmembrane helix indicated that G0S2 was probably anchored in a (sub)cellular membrane. To determine the precise intracellular localization of G0S2, a fusion construct was created between G0S2 and GFP (green fluorescent protein), which was transfected into HEK-293 cells. Because the Internet-based program PSORTII predicted G0S2 to be present in the ER, co-transfection was carried out with a marker vector for ER (pDsRed2ER). Confocal fluorescence microscopy showed that GFP fluorescence was present in discrete regions within the cytoplasm, and that it perfectly overlapped with the DsRed (Discosoma sp. red fluorescent protein) fluorescence (Figure 6A), indicating that G0S2 protein is probably present in the ER.

Unfortunately, our anti-G0S2 antibody was not functional in immunohistochemistry, which precluded localization of endogenous G0S2 protein in differentiated adipocytes. To examine whether G0S2 protein might be associated with lipid droplets, which originate from the ER, and/or to study the effect of lipid droplets on the intracellular localization of G0S2, undifferentiated 3T3-L1 cells were transfected with fusion constructs of G0S2 to GFP (Figure 6B) and DsRed (Figure 6C) and were loaded with lipids by incubation with Tween 80 . Lipid droplets were visualized with Oil Red O and BODIPY ${ }^{\circledR}$ 493/503, a green fluorescent dye that is compatible with DsRed. Fluorescence microscopy showed that G0S2 protein was present in distinct structures outside the nucleus, corresponding to the ER, and was not associated with lipid droplets.

\section{GOS2 up-regulation is specifically associated with adipogenesis}

Although our results indicate that GOS2 is highly up-regulated during 3T3-L1 and SGBS adipogenesis, it is unclear whether this effect is specific to adipocyte differentiation or whether it may extend to cell differentiation in general. To answer this question, GOS2 mRNA was monitored during $\mathrm{C} 2 \mathrm{C} 12$ osteo- and myogenesis. In this model, $\mathrm{C} 2 \mathrm{C} 12$ cells are differentiated into myoblasts by letting them grow to post-confluence or into osteoblasts by incubation with BMP-2. In clear distinction to SGBS and 3T3-L1 adipogenesis, neither C2C12 osteogenesis nor myogenesis was associated with significantly increased G0S2 expression (Figure 7). The same was true for PPAR $\gamma$. In contrast, the osteogenic marker osteocalcin showed a dramatic increase in expression during osteogenesis, while the glucose transporter GLUT4 was markedly increased during myogenesis. These results indicate that G0S2 is not involved in cell differentiation in general, but rather that GOS2 seems to be connected specifically to adipocyte differentiation.

\section{GOS2 mRNA is up-regulated during growth arrest in 3T3-L1 cells}

Adipogenesis in 3T3-L1 cells is a complex process that involves numerous steps, including clonal expansion, growth arrest, and

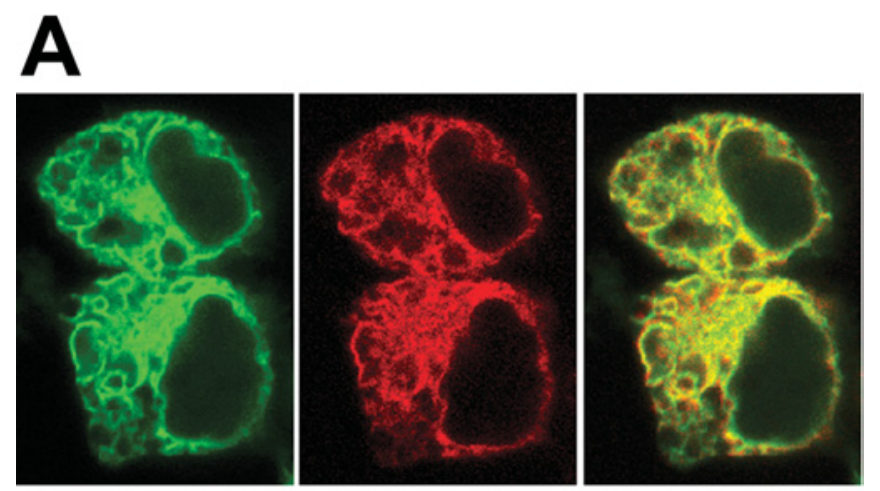

\section{.}

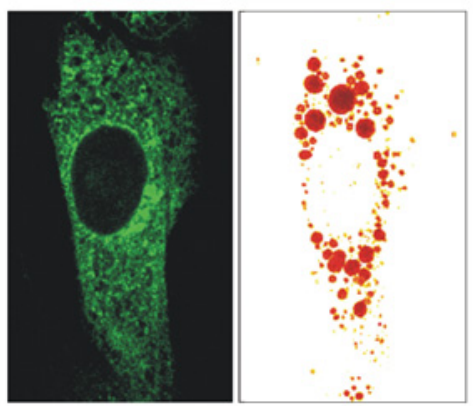

\section{C}
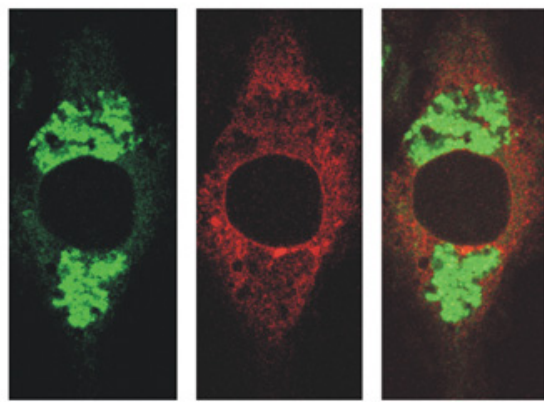

\section{Figure 6 GOS2 protein localizes to the ER}

HEK-293 cells were co-transfected with GFP-G0S2 fusion construct and ER localization vector pDsRed2-ER. (A) Left-hand panel: confocal image of GFP fluorescence. Middle panel: confocal image of DsRed fluorescence of the same cells as in the left-hand panel. Right-hand panel: overlay of left-hand and middle panels. (B) 3T3-L1 fibroblasts were transfected with fusion constructs of G0S2 to GFP and loaded with lipids by incubation with Tween 80 (0.1\%). Lipid droplets were visualized with Oil Red 0. (C) 3T3-L1 fibroblasts were transfected with fusion constructs of G0S2 to DsRed and loaded with lipids by incubation with Tween 80 (0.1\%). Lipid droplets were visualized with BODIPY ${ }^{\circledR}$ 493/503.

lipid synthesis and accumulation. In an effort to connect G0S2 to growth arrest in 3T3-L1 fibroblasts, the cells were first grown from low density to confluence, when cells should be in $\mathrm{G}_{0}$, and GOS2 mRNA expression was monitored. Interestingly, mRNA levels increased markedly when the cells reached full confluence, indicating that GOS2 expression is up-regulated in growth-arrested cells (Figure 8A). Subsequently, when cells were cell-cyclesynchronized by serum starvation, it was observed that expression of GOS2 was highest at the end of serum starvation, declined 


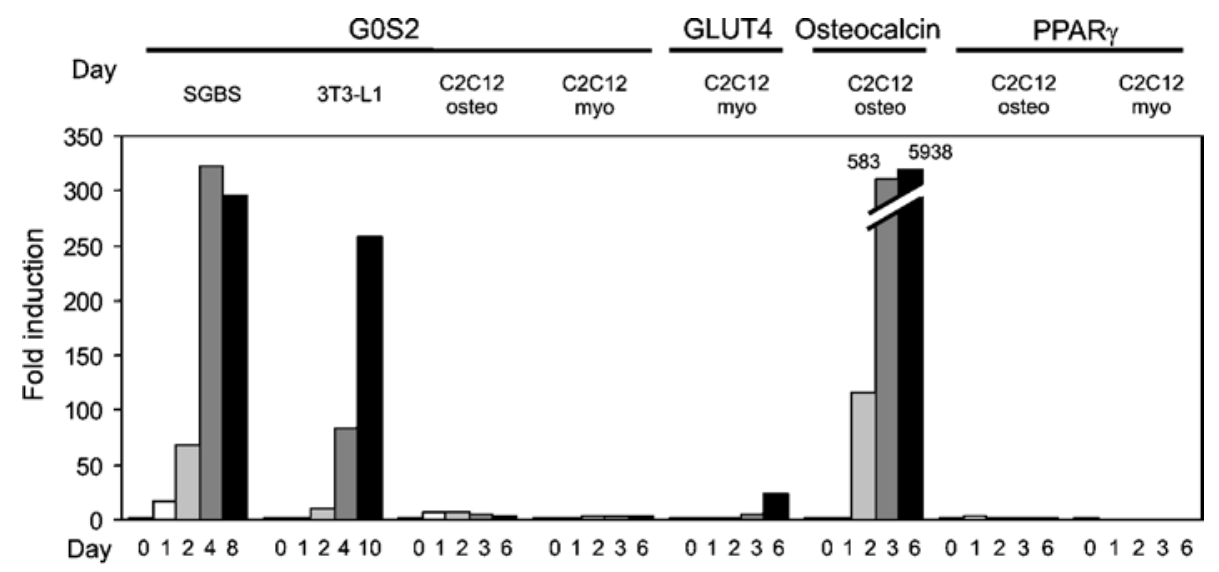

Figure 7 GOS2 is not a general marker of cell differentiation

C2C12 cells were differentiated into osteoblasts (osteo) or myoblasts (myo) by growing them to confluence in the presence or absence of BMP-2 respectively. Expression of GOS2, PPAR $\gamma$, the myogenic marker GLUT4 and the osteogenic marker osteocalcin was determined by Q-PCR. Expression of GOS2 during SGBS and 3T3-L1 adipogenesis is shown for comparison.

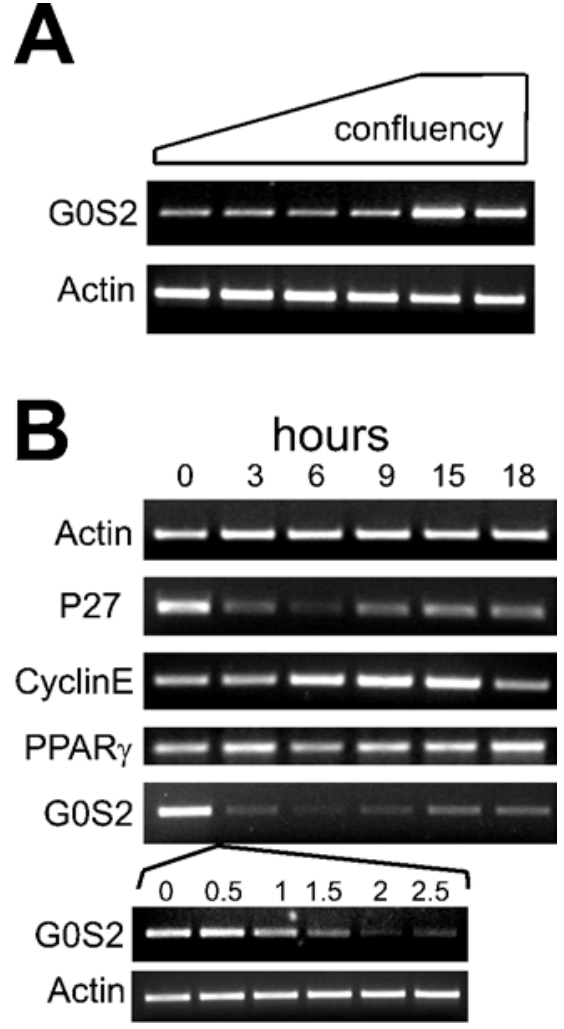

Figure 8 GOS2 mRNA is up-regulated during growth arrest

(A) 3T3-L1 fibroblasts were plated out at low density and grown to full confluence. GOS2 expression was determined by RT-PCR. (B) 3T3-L1 fibroblasts at low confluence were serum-starved $(0.2 \%$ foetal calf serum) for $33 \mathrm{~h}$. After that, foetal calf serum was re-added to the cells at $10 \%$, and cells were taken at regular intervals for RNA preparation. Expression of the genes indicated was determined by RT-PCR.

steeply in the next few hours after re-introducing serum, and reached a minimum after approx. 6-9 h, when cyclin E expression was maximal (Figure $8 \mathrm{~B}$ ). The peak of cyclin $\mathrm{E}$ expression is known to occur at the transition from the $\mathrm{G}_{1}$ to the $S$ phase. G0S2 mRNA levels almost perfectly followed those of p27, which has been implicated previously in growth arrest in 3T3L1 cells [23]. Expression of PPAR $\gamma$ did not change during serum starvation, suggesting that the fall in GOS2 mRNA is independent of PPAR $\gamma$. These results provide strong evidence that, at least in 3T3-L1 cells, G0S2 expression is highest in growth-arrested cells and is minimal at the end of $\mathrm{G}_{1}$. Inasmuch as growth arrest is required for 3T3-L1 adipogenesis, G0S2 may thus be involved in adipogenesis by being implicated in growth arrest.

\section{DISCUSSION}

Using Affymetrix microarrays, we identified the G0S2 gene as being differentially expressed between livers of PPAR $\alpha$ null mice compared with wild-type mice. Follow-up analysis subsequently showed that GOS 2 is a direct target gene of PPAR $\gamma$, and probably PPAR $\alpha$ and $\operatorname{PPAR} \beta / \delta$. Indeed, a functional PPRE could be identified in the human and mouse G0S2 promoter $1.4 \mathrm{~kb}$ upstream from the transcription start site.

However, some differences in the response to $\operatorname{PPAR} \alpha$ and $\operatorname{PPAR} \gamma$ were observed. While PPAR $\gamma$ stimulated GOS 2 promoter activity via the PPRE identified, the regulation by PPAR $\alpha$ was a bit more complex. PPAR $\alpha$ and Wy14643 failed to activate the fulllength $h G 0 S 2$ promoter, yet they decreased reporter activity after deleting the promoter to $1.0,0.5$ or $0.27 \mathrm{~kb}$. The $0.27 \mathrm{~kb}$ promoter region thus appears to be able to mediate down-regulation of $G 0 S 2$ promoter activity by $\operatorname{PPAR} \alpha$. We hypothesize that this negative regulation is compensated for by positive regulation via the PPRE at $-1.4 \mathrm{~kb}$, causing the lack of responsiveness of the full GOS2 promoter to PPAR $\alpha$. A regulation very similar to that shown by $\operatorname{PPAR} \alpha$ was observed for $\operatorname{PPAR} \beta / \delta$ (results not shown). Negative regulation by PPAR $\alpha$ may be dominant in fed (male) mouse liver, where GOS2 is expressed at a somewhat higher level in PPAR $\alpha$ null mice compared with wild-type mice (Figure 1A). Currently, the mechanism behind this regulation is still unclear.

In the absence of $\operatorname{PPAR} \alpha, G O S 2$ expression declines during fasting. The mechanism behind this decrease is unclear, but may be due to decreased insulin signalling or increased glucagon or other hormonal changes during fasting, which are compensated for by $\operatorname{PPAR} \alpha$.

Several lines of evidence suggest that GOS2 is also a target gene of $\operatorname{PPAR} \beta / \delta$ in WAT. However, since the function of PPAR $\beta / \delta$ in WAT is debatable [7,24], the functional implications of this regulation remain unclear.

A limited number of genes are known to be dual targets of PPAR $\alpha$ in liver and of PPAR $\gamma$ in adipose tissue. These include 
lipoprotein lipase, fatty acid transport protein, acyl-CoA synthase, FIAF (fasting-induced adipose factor)/ANGPTL4 (angiopoietinlike 4)/PGAR (PPAR $\gamma$ angiopoietin-related gene) and cytosolic GPDH [14,25-27]. As the roles of PPAR $\alpha$ in liver and PPAR $\gamma$ in adipose tissue are almost completely opposite (PPAR $\alpha$ : fatty acid oxidation $=$ catabolism compared with PPAR $\gamma$ : adipo/lipogenesis $=$ anabolism), the pathways supported by the target genes in the respective organs are also likely to be different. This is true for cytosolic GPDH, fatty acid transport protein, acyl-CoA synthase and, to a lesser extent, lipoprotein lipase, which are part of different pathways in the two tissues. Accordingly, it is not unreasonable to suggest that G0S2, as a dual or even triple PPAR target, might participate in different pathways in liver and adipose tissue.

The dominant expression of GOS2 in BAT and WAT, combined with the dramatic (specific) up-regulation of G0S2 during mouse and human adipogenesis and the up-regulation of GOS2 during growth arrest in 3T3-L1 cells, which is required for 3T3-L1 adipogenesis, suggest that GOS 2 may play a role in adipogenesis.

Adipogenesis describes the differentiation of pre-adipocytes into mature fat cells and has been extensively studied in vitro using 3T3-L1, 3T3-F442A and NIH-3T3 mouse fibroblasts. These studies have led to a generally accepted model of adipocyte differentiation in $3 \mathrm{~T} 3$ cells, in which a sequential up- or downregulation of several transcription factors, including E2Fs, GATAs and C/EBPs (CCAAT/enhancer-binding proteins) [28-30], brings about the emergence of an adipose phenotype via up-regulation of a large number of adipose-specific target genes. Perhaps the most important transcription factor is PPAR $\gamma$, which was demonstrated to be both necessary and sufficient for induction of an adipose phenotype [31]. Up-regulation of target genes of PPAR $\gamma$ is connected with the acquisition of functions specific to adipocytes, such as fatty acid and triacylglycerol synthesis, insulin-dependent glucose transport and the synthesis of secreted factors such as resistin and adiponectin [32,33]. The differentiation of 3T3-L1 cells into adipocytes follows a well-studied sequence of events, each of which is essential for final differentiation and development of the adipocyte phenotype. One important event is cell-cycle withdrawal/growth arrest. According to our results, G0S2 may be associated with 3T3-L1 adipogenesis by its involvement in growth arrest.

Currently, the role of G0S2 in non-adipose tissues, such as liver, is not clear and, based on the previous argument, may diverge from its function in adipose tissue. Highest expression of GOS2 is found in adipose tissue, but mRNA levels are also reasonably high in liver, heart and other tissues. The very low expression of GOS2 in rapidly proliferating hepatoma cell lines (HepG2, FAO, Hepa1-6) in comparison with growth-arrested mouse liver suggests that the possible role of G0S2 in growth arrest/differentiation may extend beyond adipose tissue. At the same time, our studies in $\mathrm{C} 2 \mathrm{C} 12$ cells clearly indicate that G0S2 is not a general marker of cell differentiation. Further studies are necessary to determine the role of G0S2 in non-adipose tissues.

G0S2 was initially discovered using differential hybridization in blood mononuclear cells as a gene that is very transiently induced after treatment with concanavalin A (a lectin), cycloheximide (a protein synthesis inhibitor) and the combination of PMA (a phorbol ester) and ionomycin (a calcium ionophore) [21]. This rapid and transient increase in expression was inhibited by cyclosporin A. These results led the authors to conclude that GOS2 expression is transiently induced upon re-entry of cells into the $\mathrm{G}_{1}$ phase of the cell cycle and would be required to commit cells to enter $\mathrm{G}_{1}$ [21]. In contrast, our results indicate that up-regulation of GOS2 is associated with cell-cycle withdrawal. The reason for this discrepancy is not clear, but it may point to a cell-type-specific function for G0S2. Alternatively, transient up-regulation of G0S2 in blood mononuclear cells by any of the compounds mentioned above may reflect a different event from re-entry into the cell cycle.

The limited information available about GOS2 before the present study included an in situ hybridization analysis of GOS2 expression in mice embryos. It was found that, at day 18.5, GOS2 expression is restricted to BAT and WAT [34]. The present study confirms that GOS2 is mainly expressed in WAT and BAT, but also indicates that GOS2 mRNA is reasonably well expressed in other tissues, such as lung, liver and heart. The reason for this discrepancy is not exactly clear, but it may be due to a difference in sensitivity between the techniques used to detect GOS 2 mRNA (in situ hybridization compared with Q-PCR) or a difference in the age of the animal (embryonic day 18.5 compared with adult animal). The latter explanation would support a role for G0S2 in growth arrest, since, at the embryonic stage, tissues such as muscle and liver still display a high rate of cell proliferation, whereas, in the adult stage, liver and muscle cells are highly differentiated and arrested in $\mathrm{G}_{0}$, which would result in increased G0S2 expression.

In the present study, G0S2 protein was localized to the ER. Analysis of the primary sequence by the Internet-based PSORT II program predicted the N-terminal domain comprising amino acids 1-26 to be protruding into the cytoplasm, whereas the Cterminal domain comprising amino acids $43-103$ is expected to be in the ER lumen. The molecular mechanism by which G0S2 may influence growth arrest and, accordingly, adipogenesis would probably involve some kind of protein-protein interaction via either of these domains. Future studies will have to address this in more detail.

Finally, our microarray experiment corroborated perfectly the concept that $\operatorname{PPAR} \alpha$ is an important regulator of fatty acid oxidation and ketogenesis, and that the function of PPAR $\alpha$ becomes mainly evident during fasting. Possible new target genes of $\operatorname{PPAR} \alpha$ that emerged from our microarray screen include those for insulin-like growth factor-binding protein 2, folylpolyglutamate synthetase and LDL (low-density lipoprotein)-receptor-related protein 1 . These results underscore the utility of microarray analysis in finding and characterizing novel potential target genes of nuclear hormone receptors.

In conclusion, we have identified the GOS2 as a novel direct target gene of $\operatorname{PPAR} \gamma$, and probably $\operatorname{PPAR} \alpha$ and $\operatorname{PPAR} \beta / \delta$, and present results suggesting that it is involved in adipocyte differentiation.

We are grateful to Dr Wilma Steegenga for the RT samples from C2C12 cells, and Dr M. Wabitsch for the gift of the SGBS cell line. We thank Erika Ferguson for excellent technical assistance, Yixin Wang for his support in microarray data analysis, Ken (Gang) Hu for his advice in GeneSpring program, Gary McMaster and Steven Hunt for their support to carry out the microarray study. This study was financed by the Netherlands Organization for Scientific Research (NWO), with additional support from the Royal Netherlands Academy of Art and Sciences (KNAW), the Wageningen Center for Food Sciences, the Swiss National Science Foundation and the Human Frontier Science Program (HFSP). We declare no conflict of interest.

\section{REFERENCES}

1 Kersten, S., Desvergne, B. and Wahli, W. (2000) Roles of PPARs in health and disease. Nature (London) 405, 421-424

2 Tontonoz, P., Hu, E. and Spiegelman, B. M. (1994) Stimulation of adipogenesis in fibroblasts by PPAR $\gamma 2$, a lipid-activated transcription factor. Cell 79, 1147-1156

3 Barak, Y., Nelson, M. C., Ong, E. S., Jones, Y. Z., Ruiz-Lozano, P., Chien, K. R., Koder, A. and Evans, R. M. (1999) PPAR $\gamma$ is required for placental, cardiac, and adipose tissue development. Mol. Cell 4, 585-595

4 Ren, D., Collingwood, T. N., Rebar, E. J., Wolffe, A. P. and Camp, H. S. (2002) PPAR knockdown by engineered transcription factors: exogenous PPAR $\gamma 2$ but not PPAR $\gamma 1$ reactivates adipogenesis. Genes Dev. 16, 27-32 
5 Rosen, E. D., Hsu, C. H., Wang, X., Sakai, S., Freeman, M. W., Gonzalez, F. J. and Spiegelman, B. M. (2002) C/EBP $\alpha$ induces adipogenesis through PPAR $\gamma$ : a unified pathway. Genes Dev. 16, 22-26

6 Way, J. M., Harrington, W. W., Brown, K. K., Gottschalk, W. K., Sundseth, S. S., Mansfield, T. A., Ramachandran, R. K., Willson, T. M. and Kliewer, S. A. (2001) Comprehensive messenger ribonucleic acid profiling reveals that peroxisome proliferator-activated receptor gamma activation has coordinate effects on gene expression in multiple insulin-sensitive tissues. Endocrinology 142, 1269-1277

7 Wang, Y. X., Lee, C. H., Tiep, S., Yu, R. T., Ham, J., Kang, H. and Evans, R. M. (2003) Peroxisome-proliferator-activated receptor $\delta$ activates fat metabolism to prevent obesity. Cell 113, 159-170

8 Wang, Y. X., Zhang, C. L., Yu, R. T., Cho, H. K., Nelson, M. C., Bayuga-Ocampo, C. R., Ham, J., Kang, H. and Evans, R. M. (2004) Regulation of muscle fiber type and running endurance by PPARS. PLoS Biol. 2, E294

9 Akiyama, T. E., Lambert, G., Nicol, C. J., Matsusue, K., Peters, J. M., Brewer, Jr, H. B. and Gonzalez, F. J. (2004) Peroxisome proliferator-activated receptor $\beta / \delta$ regulates very low density lipoprotein production and catabolism in mice on a Western diet. J. Biol. Chem. 279, 20874-20881

10 Di Poi, N., Tan, N. S., Michalik, L., Wahli, W. and Desvergne, B. (2002) Antiapoptotic role of $\operatorname{PPAR} \beta$ in keratinocytes via transcriptional control of the Akt1 signaling pathway. Mol. Cell 10, 721-733

11 Harman, F. S., Nicol, C. J., Marin, H. E., Ward, J. M., Gonzalez, F. J. and Peters, J. M. (2004) Peroxisome proliferator-activated receptor- $\delta$ attenuates colon carcinogenesis. Nat. Med. 10, 481-483

12 Gupta, R. A., Wang, D., Katkuri, S., Wang, H., Dey, S. K. and DuBois, R. N. (2004) Activation of nuclear hormone receptor peroxisome proliferator-activated receptor- $\delta$ accelerates intestinal adenoma growth. Nat. Med. 10, 245-247

13 Mandard, S., Müller, M. and Kersten, S. (2004) Peroxisome proliferator-activated receptor $\alpha$ target genes. Cell. Mol. Life Sci. 61, 393-416

14 Patsouris, D., Mandard, S., Voshol, P. J., Escher, P., Tan, N. S., Havekes, L. M., Koenig, W., Marz, W., Tafuri, S., Wahli, W. et al. (2004) PPAR $\alpha$ governs glycerol metabolism. J. Clin. Invest. 114, 94-103

15 Gervois, P., Kleemann, R., Pilon, A., Percevault, F., Koenig, W., Staels, B. and Kooistra, T. (2004) Global suppression of IL-6-induced acute phase response gene expression after chronic in vivo treatment with the peroxisome proliferator-activated receptor- $\alpha$ activator fenofibrate. J. Biol. Chem. 279, 16154-16160

16 Delerive, P., Fruchart, J. C. and Staels, B. (2001) Peroxisome proliferator-activated receptors in inflammation control. J. Endocrinol. 169, 453-459

17 Beigneux, A. P., Moser, A. H., Shigenaga, J. K., Grunfeld, C. and Feingold, K. R. (2000) The acute phase response is associated with retinoid $X$ receptor repression in rodent liver. J. Biol. Chem. 275, 16390-16399

18 Moshage, H., Casini, A. and Lieber, C. S. (1990) Acetaldehyde selectively stimulates collagen production in cultured rat liver fat-storing cells but not in hepatocytes. Hepatology 12, 511-518

19 Wabitsch, M., Brenner, R. E., Melzner, I., Braun, M., Moller, P., Heinze, E., Debatin, K. M. and Hauner, H. (2001) Characterization of a human preadipocyte cell strain with high capacity for adipose differentiation. Int. J. Obes. Relat. Metab. Disord. 25, $8-15$

Received 20 April 2005/29 July 2005; accepted 9 August 2005

Published as BJ Immediate Publication 9 August 2005, doi:10.1042/BJ20050636
20 Kersten, S., Mandard, S., Tan, N. S., Escher, P., Metzger, D., Chambon, P., Gonzalez, F. J., Desvergne, B. and Wahli, W. (2000) Characterization of the fasting-induced adipose factor FIAF, a novel peroxisome proliferator-activated receptor target gene. J. Biol. Chem. $\mathbf{2 7 5}$, 28488-28493

21 Russell, L. and Forsdyke, D. R. (1991) A human putative lymphocyte $G_{0} / G_{1}$ switch gene containing a $\mathrm{CpG}$-rich island encodes a small basic protein with the potential to be phosphorylated. DNA Cell Biol. 10, 581-591

22 Berger, J., Leibowitz, M. D., Doebber, T. W., Elbrecht, A., Zhang, B., Zhou, G., Biswas, C., Cullinan, C. A., Hayes, N. S., Li, Y. et al. (1999) Novel peroxisome proliferator-activated receptor (PPAR) $\gamma$ and PPAR $\delta$ ligands produce distinct biological effects. J. Biol. Chem. 274, 6718-6725

23 Morrison, R. F. and Farmer, S. R. (1999) Role of PPAR $\gamma$ in regulating a cascade expression of cyclin-dependent kinase inhibitors, $18^{\text {INK4C }}$ and p21 Wart/Cip1, during adipogenesis. J. Biol. Chem. 274, 17088-17097

24 Matsusue, K., Peters, J. M. and Gonzalez, F. J. (2004) PPAR $\beta / \delta$ potentiates PPAR $\gamma$-stimulated adipocyte differentiation. FASEB J. 18, 1477-1479

25 Martin, G., Schoonjans, K., Lefebvre, A. M., Staels, B. and Auwerx, J. (1997) Coordinate regulation of the expression of the fatty acid transport protein and acyl-CoA synthetase genes by PPAR $\alpha$ and PPAR $\gamma$ activators. J. Biol. Chem. 272, 28210-28217

26 Schoonjans, K., Peinado-Onsurbe, J., Lefebvre, A. M., Heyman, R. A., Briggs, M., Deeb, S., Staels, B. and Auwerx, J. (1996) PPAR $\alpha$ and PPAR $\gamma$ activators direct a distinct tissue-specific transcriptional response via a PPRE in the lipoprotein lipase gene. EMBO J. 15, 5336-5348

27 Mandard, S., Zandbergen, F., Tan, N. S., Escher, P., Patsouris, D., Koenig, W., Kleemann, R., Bakker, A., Veenman, F., Wahli, W. et al. (2004) The direct peroxisome proliferator-activated receptor target fasting-induced adipose factor (FIAF/PGAR/ANGPTL4) is present in blood plasma as a truncated protein that is increased by fenofibrate treatment. J. Biol. Chem. 279, 34411-34420

28 Fajas, L., Landsberg, R. L., Huss-Garcia, Y., Sardet, C., Lees, J. A. and Auwerx, J. (2002) E2Fs regulate adipocyte differentiation. Dev. Cell 3, 39-49

29 Tong, Q., Dalgin, G., Xu, H., Ting, C. N., Leiden, J. M. and Hotamisligil, G. S. (2000) Function of GATA transcription factors in preadipocyte-adipocyte transition. Science 290, 134-138

30 Christy, R. J., Yang, V. W., Ntambi, J. M., Geiman, D. E., Landschulz, W. H., Friedman, A. D., Nakabeppu, Y., Kelly, T. J. and Lane, M. D. (1989) Differentiation-induced gene expression in 3T3-L1 preadipocytes: CCAAT/enhancer binding protein interacts with and activates the promoters of two adipocyte-specific genes. Genes Dev. 3, 1323-1335

31 Rosen, E. D. and Spiegelman, B. M. (2001) PPAR : a nuclear regulator of metabolism, differentiation, and cell growth. J. Biol. Chem. 276, 37731-37734

32 Steppan, C. M., Bailey, S. T., Bhat, S., Brown, E. J., Banerjee, R. R., Wright, C. M., Patel, H. R., Ahima, R. S. and Lazar, M. A. (2001) The hormone resistin links obesity to diabetes. Nature (London) 409, 307-312

$33 \mathrm{Hu}$, E., Liang, P. and Spiegelman, B. M. (1996) AdipoQ is a novel adipose-specific gene dysregulated in obesity. J. Biol. Chem. 271, 10697-10703

34 Bachner, D., Ahrens, M., Schroder, D., Hoffmann, A., Lauber, J., Betat, N., Steinert, P., Flohe, L. and Gross, G. (1998) Bmp-2 downstream targets in mesenchymal development identified by subtractive cloning from recombinant mesenchymal progenitors (C3H10T1/2). Dev. Dyn. 213, 398-411 